\title{
Estimation of Phenotypic Coefficients of Variation (PCV), Genotypic Coefficients of Variation (GCV), Heritability and Genetic Gain for Yield and its Components in Rice Landraces of Odisha
}

\author{
Pinaky Dey, Simanchal Sahu and Rajesh Kumar Kar" \\ Department of Plant Breeding \& Genetics, College of Agriculture, OUAT, Bhubaneswar, Odisha, India \\ *Corresponding author: rajeshkar023@gmail.com (ORCID ID: 0000-0002-4203-0983)
}

Paper No. 782

Received: 07-04-2019

Revised: 02-07-2019

Accepted: 25-08-2019

\begin{abstract}
The present investigation was carried out to study genetic variability in sixty-four low land rice genotypes (including fifty-five landraces of Odisha) for twelve traits. Analysis of variance (ANOVA) revealed significant differences among the genotypes for all the studied characteristics. Flag leaf area, effective tillers per plant, filled grains per panicle, 100-grain weight and harvest index had moderate to high phenotypic coefficients of variation (PCV) and genotypic coefficients of variation (GCV) estimates suggesting that these traits are under the influence of genetic control and less affected by the environment. In the present study, all the characters exhibited a high degree of heritability and among those flag leaf area, number of filled grains per panicle, 100-grain weight, harvest index and grain yield per plant had high genetic advance indicating the presence of additive gene effect and hence selection based on phenotypic performance for these traits would be effective. Filled grains per panicle and flag leaf area followed by 100-grain weight and harvest index are important characters having high heritability, genetic advance as well as high coefficient of variation which should be considered while selecting for high yield.
\end{abstract}

\section{Highlights}

( V Variability present among different local landraces of rice for different yield and yield attributing characters were studied.

Keywords: Genetic advance, genetic variability, genotypic coefficients of variation GCV, heritability, phenotypic coefficients of variation PCV, rice landraces

Rice (Oryza sativa L.) is one of the major cereal grains which serve as staple food for a major part of world's population (FAO, 2017). During 2017 and 2018, India is the second largest producer after China with a production of 166.5 million metric tons (Statista 2019). Rice is grown in different agro-ecosystems such as irrigated, rainfed upland, rainfed lowland and flood prone areas.

Odisha had rice grown area of 3963000 hectare with production of 97.94 lakh metric tons during the year 2016-17 (Odisha Economic Survey, 2017-18). In India there are more than 50,000 rice varieties, but unfortunately most of these varieties are fast vanishing because of faulty agricultural practices (Mishra and Sinha 2012). Now a day's farmers are mostly growing high yielding varieties which have developed through few races of rice and have stopped cultivating local varieties. Generally the high yielding varieties have lower adaptability and susceptible to different biotic and abiotic stresses. But local varieties are of enormous value in agriculture as they are the store house of infinite important genes as they have evolved in particular environment since millions of years. (Mishra and Sinha 2012). 
Unlike high yielding varieties, landraces anchorage a great genetic potential for rice improvement. They are endowed with tremendous variability. This rich variability of complex quantitative traits still remains unutilized. Genetic improvement mainly depends on the amount of genetic variability present in the germplasm (Govindaraj et al. 2015). In Odisha, a large number of local landraces of rice are available which contribute to genetic variability for different characters. Collection, characterization and evaluation of landraces are essential part of the pre breeding process prior to rice improvement Realizing the importance, fifty five local landraces of rice cultivated in rainfed lowland situation which was collected from different parts of Odisha were investigated along with high yielding checks to assess the variability present among different local landraces of rice for different yield and yield attributing characters.

\section{MATERIALS AND METHODS}

The experiment was conducted by taking fifty-five rice landraces of Odisha, four improved varieties and five high yielding varieties suitable for lowland ecology. The experiment was conducted at Rice Research Station, Odisha University of Agriculture and Technology, Bhubaneswar during kharif, 2014. The experimental materials were evaluated in randomized block design RBD with two replications with spacing of $20 \mathrm{~cm} \times 15 \mathrm{~cm}$. The recommended cultural practices and need based plant protection measures were followed to raise a normal crop. Observations were recorded in respect of all twelve morphological characters viz., plant height $(\mathrm{PH})$, flag leaf area (FLA), effective tillers per plant (EBT), panicle length (PL), fertility percentage (FP), filled grains per panicle (FGP), straw yield per plant (SYP), 100-grain weight (GW), grain yield per plant (GYP), harvest index $(\mathrm{HI})$ and grain Length/Breadth ratio (LB) on five competitive plants from each replication selected randomly from the middle row of each plot, where as character like days to $50 \%$ flowering (DF) was recorded on plot basis. The recorded data were subjected to statistical analysis based on the sample mean for different studied characters.. The data were analysed by using analysis of variance ANOVA (Panse and Sukhatme 1961) and the genetic parameters such as phenotypic coefficient of variance $(\mathrm{PCV})$ and genotypic coefficient of variance (GCV) were calculated by the formula proposed by
(Burton, 1952), heritability in broad sense by (Burton and DeVane 1953), and genetic advance in per cent of mean were calculated as suggested by (Johnson et al. 1955).

\section{RESULTS AND DISCUSSION}

A set of sixty four lowland rice genotypes involving fifty five local landraces collected from fourteen districts of Odisha, four improved and five high yielding genotypes were evaluated in rainfed lowland situation at the Rice Research Station of Department of Plant Breeding and Genetics, OUAT, Bhubaneswar during kharif 2014. Different yield and yield attributing traits were examined to study the extent of genetic variability.

Presence of genetic variability is a primary prerequisite in any crop improvement programme. The genetic variability in respect of a trait is the direct measure as to how far the character could be manipulated in a desired direction. From the variance analysis (Table 1) significant amount of genetic variation was displayed for traits like days to 50\% flowering, plant height, flag leaf area, effective tillers per plant, panicle length, fertility percentage, filled grains per panicle, straw yield per plant, 100-grain weight, harvest index, grain $\mathrm{L} / \mathrm{B}$ ratio and grain yield per plant. Characters having higher magnitude of genetic variance such as filled grains per panicle, plant height, fertility percentage and flag leaf area maybe sorted out as important selection criteria for realization of higher productivity in rice.

Phenotypic coefficient of variation (PCV) and genotypic coefficient variation (GCV) estimates indicated the existence of the significant amount of variability among the genotypes for all the studied characters (Table 1). In the present study, all the characters showed slightly higher PCV than GCV, but the difference was very less signifying less influence of the environment. Therefore, selection on the basis of phenotype for most of the characters is likely to be effective.

Among all the characters studied, GCV ranged from 2.82 for days to $50 \%$ flowering to 26.10 in grain yield per plant, and PCV ranged from 3.02 for days to $50 \%$ flowering to 27.00 for grain yield per plant (Table 2). Characters namely flag leaf area, effective tillers per plant, filled grains per panicle, 100-grain weight and harvest index had moderate to 
Estimation of Phenotypic Coefficients of Variation (PCV), Genotypic Coefficients of Variation...

Table 1: Analysis of variance of twelve characters (mean sum of squares) for 64 lowland rice genotypes

\begin{tabular}{ccccc}
\hline S1. No. & Character & \multicolumn{3}{c}{ Source of variation(df) } \\
\hline & & Replication (1) & Genotype (63) & Error (63) \\
\hline 1 & Days to 50\% flowering & 18.625 & $21.605^{* *}$ & 2.696 \\
2 & Plant height (cm) & 42.750 & $745.071^{* *}$ & 135.528 \\
3 & Flag leaf area $\left(\mathrm{cm}^{2}\right)$ & 0.266 & $30.030^{* *}$ & 11.702 \\
4 & Effective tillers/plant & 0.321 & $13.587^{* *}$ & 1.067 \\
5 & Panicle length (cm) & 0.461 & $1625.599^{* *}$ & 1.463 \\
6 & Filled grains per panicle & 668.000 & $174.691^{* *}$ & 481.885 \\
7 & Fertility percentage (\%) & 2.438 & $0.500^{* *}$ & 43.641 \\
8 & 100 -grain weight & 0.227 & $0.403^{* *}$ & 0.030 \\
9 & Grain L/B ratio & 0.016 & $40.217^{* *}$ & 0.015 \\
11 & Straw yield/plant (g) & -0.016 & $0.008^{* *}$ & 3.806 \\
12 & Harvest index & 0.001 & $19.810^{* *}$ & 0.001 \\
\hline
\end{tabular}

* Significant at 5\% level of probability, ** Significant at 1\% level of probability.

Table 2: PCV, GCV, $\mathrm{h}^{2}$ and GA estimates for various characters of sixty four low land rice genotypes

\begin{tabular}{|c|c|c|c|c|c|c|c|c|}
\hline $\begin{array}{l}\text { S1. } \\
\text { No. }\end{array}$ & Characters & Mean & Range & PCV (\%) & GCV (\%) & $\begin{array}{c}\text { Heritability } \\
(\%)\end{array}$ & GA (5\%) & $\begin{array}{c}\text { GA }(\% \text { of } \\
\text { Mean) }\end{array}$ \\
\hline 1 & Days to $50 \%$ flowering & 108.90 & $100.50-121.00$ & 3.02 & 2.82 & 87.52 & 5.06 & 4.65 \\
\hline 3 & Flag leaf area $\left(\mathrm{cm}^{2}\right)$ & 34.95 & $19.32-51.53$ & 23.07 & 22.01 & 91.00 & 12.91 & 36.95 \\
\hline 4 & Effective tillers/plant & 6.29 & 4.25- 9.66 & 22.40 & 19.15 & 73.12 & 1.81 & 28.83 \\
\hline 7 & Fertility percentage (\%) & 79.10 & 36.15- 95.05 & 11.82 & 10.23 & 75.02 & 12.34 & 15.60 \\
\hline 8 & 100 -grain weight (g) & 2.13 & 1.08- 3.11 & 23.43 & 22.71 & 93.95 & 0.83 & 38.73 \\
\hline 9 & Grain L/B ratio & 4.10 & 2.88-5.30 & 10.95 & 10.74 & 96.17 & 0.76 & 18.53 \\
\hline 10 & Straw yield/plant (g) & 26.17 & $14.16-39.17$ & 17.14 & 16.31 & 90.54 & 7.15 & 27.31 \\
\hline
\end{tabular}

Table 3: Important characters to be considered during selection

\begin{tabular}{|c|c|c|c|c|c|}
\hline Characters & $\begin{array}{c}\text { Higher magnitude } \\
\text { of variance }\end{array}$ & $\begin{array}{l}\text { Moderate to high } \\
\text { PCV and GCV }\end{array}$ & Heritability & $\begin{array}{l}\text { Genetic } \\
\text { advance }\end{array}$ & Rank \\
\hline Days to $50 \%$ flowering & - & - & - & $\sqrt{ }$ & \\
\hline Plant height $(\mathrm{cm})$ & $\sqrt{ }$ & - & - & $\sqrt{ }$ & \\
\hline Flag leaf area $\left(\mathrm{cm}^{2}\right)$ & $\sqrt{ }$ & $\sqrt{ }$ & $\sqrt{ }$ & $\sqrt{ }$ & 1 \\
\hline Effective tillers/plant & - & $\sqrt{ }$ & - & $\sqrt{ }$ & \\
\hline Panicle length (cm) & - & - & - & $\sqrt{ }$ & \\
\hline Fertility percentage (\%) & $\sqrt{ }$ & - & - & $\sqrt{ }$ & \\
\hline 100 -grain weight (g) & - & $\sqrt{ }$ & $\sqrt{ }$ & $\sqrt{ }$ & 2 \\
\hline Grain L/B ratio & - & - & - & $\sqrt{ }$ & \\
\hline Straw yield/plant(g) & - & - & - & $\sqrt{ }$ & \\
\hline
\end{tabular}


high PCV and GCV estimates suggesting that these traits are under the influence of genetic control and less affected by environment. Hence, these traits can be relied upon, and simple selection can be practiced for further improvement. Similar findings were also reported by Idris et al. (2012) for filled grains per panicle and harvest index; Seyoum et al. 2012 for 1000-grain weight and grains per panicle; Gangashetty et al. (2013) for effective ear bearing tillers per plant.

Heritability is an estimate of the ratio of genotypic variance to the total phenotypic variance. Very high to high degree of heritability estimates were observed for all the traits under study indicating the low or negligible influence of environment in the expression of these traits and may respond to selection for their improvement. However, broad sense heritability is also subjected to some experimental error. Hence, genetic advance along with heritability gives more reliable information for consideration of a character under selection. The expected amount of genetic advance can be estimated by the genotypic coefficient of variation along with heritability as suggested by Burton (1952).

In the present study, all the twelve characters exhibited high degree of heritability and among those flag leaf area, filled grains per panicle, 100-grain weight, harvest index and grain yield per plant had high genetic advance indicating the presence of additive gene effect and hence selection based on phenotypic performance for these traits would be effective. Similar observations were also recorded by Jaiswal et al. (2007) for grain yield per plant; Kole et al. (2008) for grain number and grain yield; Pandey et al. (2009) for effective ear bearing tillers per hill, test weight, harvest index and grain yield; Subudhi et al. (2009) for grains per panicle; Pfukrei et al. (2011) for grain yield per plant; Immanuel et al. (2011) for harvest index; Selvaraj et al. (2011) for grain yield per plant; Gangashetty et al. (2013) for grain yield per plant; Akinwale et al. (2011) for grains per panicle and grain yield.

Table 3 reveals that characters namely filled grains per panicle and flag leaf area followed by 100-grain weight and harvest index are important characters having high heritability, genetic advance as well as high coefficient of variation which should be considered while selecting for high yield. The following genotypes were identified as promising with respect to the said characters.

\begin{tabular}{|l|l|l|}
\hline $\begin{array}{l}\text { Sl. } \\
\text { No. }\end{array}$ & Character & Promising genotypes \\
\hline 1 & $\begin{array}{l}\text { Filled grains/ } \\
\text { panicle }\end{array}$ & $\begin{array}{l}\text { Badashabhoga, Kanchan, } \\
\text { Kadalipendi, Ranisaheba, } \\
\text { Ganjeijata, Ganjamgedi, } \\
\text { Parvatajeera, Juiphoola and } \\
\text { Karpurakranti }\end{array}$ \\
\hline 2 & $\begin{array}{l}\text { Flag leaf area } \\
\left.\text { cm }^{2}\right)\end{array}$ & $\begin{array}{l}\text { Jalagudi, Bhutia, Madhabi, } \\
\text { Gunjimanika, Khandasagar, } \\
\text { Mayurakantha, Jaladubi, } \\
\text { Dhoiabankoi and Biradiabankoi }\end{array}$ \\
\hline 3 & $\begin{array}{l}100 \text {-grain } \\
\text { weight (g) }\end{array}$ & $\begin{array}{l}\text { Jaladubi, Kalakadamba, } \\
\text { Biradiabankoi, Nilarpati, } \\
\text { Champeisiali, FR 13A, Mahipal, } \\
\text { Dhoiabankoi, Habira, Bankoi, T } \\
\text { 1242, Baudiachampa and Dhulia }\end{array}$ \\
\hline 4 & $\begin{array}{l}\text { Harvest } \\
\text { index }\end{array}$ & $\begin{array}{l}\text { Ganjamgedi, T 141, FR 13A, } \\
\text { Mrunalini, Seulapana, Madhabi, } \\
\text { Dhulia, Nilarpati, Kanchan, } \\
\text { Jagabalia, Kadalipendi and } \\
\text { Ganjeijata }\end{array}$ \\
\hline
\end{tabular}

\section{REFERENCES}

Akinwale, M.G., Gregorio, G., Nwilene, F., Akinyele, B.O., Ogunbayo, S.A. and Odiyi, A.C. .2011. Heritability and correlation coefficient analysis for yield and its componenets in rice (Oryza sativa L.). African Journal of Plant Science, 5(3): 207-212.

Burton, G.W. 1952. Quantitative inheritance of grasses.Proc. $6^{\text {th }}$ int. Grassland Congress, 1: 277-283.

Burton, G.W. and DeVane, E.H. 1953. Estimating heritabil-ity in tall fescue (Festucaarundinacea) from replicated clonal material. Agronomy Journal, 45: 478-481.

FAO (Food and Agriculture Organization of the United Nations). 2017. Retrieved from http://www.fao.org/ faostat.

Gangashetty, P., Salimath, P. and Hanamaratti, N. 2013.Genetic variability studies in genetically diverse non-basmati local aromatic genotypes of rice (Oryza sativa). Rice Genomics and Genetics, 2: 4-8.

Govindaraj, M. Vetriventhan, M. and Srinivasan, M. 2015. Importance of Genetic Diversity Assessment in Crop Plants and Its Recent Advances: An Overview of Its Analytical Perspectives, Genetics Research International, http://dx.doi.org/10.1155/2015/431487.

Idris, A.E., Justin, F.J., Dagash, Y.M.I. and Abduli, A.I. 2012. Genetic variability and inter relationship between yield and yield components in some rice genotypes, American Journal of Experimental Agriculture, 2(2): 233-239.

Jaiswal, H.K., Shrivastava, A.K. and Dey, A. 2007. Variability, correlation and path analysis for yield and quality traits in indigenous aromatic rice genotypes. Oryza, 44 (4): 395. 
Johnson, H.W., Robinson, H.F. and Comstock, R.E. 1955. Estimation of genetic and environmental variability in soybean. Agronomy Journal, 47: 314-318.

Kole, P.C., Chakraborty, N.R. and Bhat, J.S. 2008. Analysis of variability, correlation and path coefficients in induced mutants of aromatic non-basmati rice. Tropical Agricultural Research E Extension, 11: 15-21.

Mishra, P.K. and Sinha, A.K. 2012. Rice diversity in bankura district of West bengal (India), Bioscience discovery, 3(3): 284-287.

Odisha Economic Survey. 2017-18/https://pc.odisha.gov.in/ Download/Economic_Survey_2017-18.pdf.

Pandey, P., Anurag, P.J., Tiwari, D.K., Yadav, S.K. and Kumar, B. 2009. Genetic variability, diversity and association of quantitative traits with grain yield in rice (Oryza sativa L.). Journal of bioscience, 17: 77-82.

Panse, V.G. and Sukhatme, P.V. 1961. Statistical methods for agricultural workers. $2^{\text {nd }}$ Edition ICAR, New Delhi, pp. 361.
Pfukrei, P.K., Kumar, A., Tyagi, W., Rai, M., Pattanayak, A. 2011. Genetic variability in yield and its components in upland rice grown in acid soils of North-East India, Journal of Rice Research, 4(1 \& 2): 4-7.

Seyoum, M., Alamerew, S., and Bantte, K. 2012. Genetic variability, heritability, correlation coefficient and path analysis for yield and yield related traits in upland rice (Oryza sativa L.). Journal of Plant Science, 7(1): 13-22.

Selvaraj, C.I., Nagarajan, P.,Thiyagarajan, K., Bharathi, M. and Rabindran, R. 2011. Genetic parameters of variability, correlation and path coefficient studies for grain yield and other yield attributes among rice blast disease resistant genotypes of rice (Oryza sativa L.), African Journal of Biotechnology, 10(17): 3322-3334.

Statista. 2019. Retrived from https://www.statista.com/ statistics/255937/leading-rice-producers-worldwide.

Subudhi, H.N. and Dikshit, N. 2009. Variability and Character Association of Yield Components in Rainfed Lowland Rice. Indian Journal of Plant Genetic Resources, 22(1): 31-35. 
